\title{
Using Visual Art in Product Design and Consumer Responses: The Moderating Role of Product Type
}

\author{
Aylin Ecem Gürşen \\ Department of Business Administration, Galatasaray University, Istanbul, Turkey \\ aegursen@gsu.edu.tr \\ Erdem Özkan \\ Department of Marketing, School of Business, Istanbul University, Istanbul, Turkey \\ erdem.ozkan@istanbul.edu.tr \\ Zehra Bozbay \\ Department of Marketing, School of Business, Istanbul University, Istanbul, Turkey \\ zehrat@istanbul.edu.tr
}

\begin{abstract}
This paper aims to determine the effects of using visual art in designing non-luxury products on consumers' luxury perceptions, quality perceptions, and product evaluations. An experimental design was conducted to test these effects. Differences according to the product types (convenience vs. shopping) were also evaluated. The research sample consisted of young consumers. The data was collected from 400 university students via a face-to-face survey and analyzed by using two-way MANCOVA. Results demonstrate that using visual art in the non-luxury product design affects perceived quality, luxury perception, and product evaluation both independently and interacting with the product type. Besides, using visual art in the convenience product without technical details increases consumers' positive evaluations. In this context, product type has a moderating role in the effects of using visual art on product evaluation. Accordingly, art infusion increases positive product evaluation for convenience products but decreases it for shopping products.
\end{abstract}

Keywords: Visual art, Art infusion, Product design, Perceived quality, Luxury perception, Product evaluation 


\section{INTRODUCTION}

Consumers are faced with a wide variety of products in today's markets. Differentiating factors are pretty significant in consumers' product evaluations in such markets, and the design stands out as a substantial product differentiation factor (Hoegg et al., 2010). A product's design is also accepted as an essential tool for attraction, communication, and value creation (Bloch, 1995; Chitturi et al., 2008). As a result, product design is a significant source in achieving a competitive advantage for companies.

A product design includes the composition of visual and non-visual elements (Homburg et al., 2015). Art elements are among them. By using these elements in product designs more and more, companies try to influence consumer evaluations. Such activities are considered within the scope of the art infusion in the literature. The art infusion, which is a phenomenon introduced by Hagtvedt and Patrick (2008a), represents the effects of using art elements in product design on consumer perceptions and evaluations of products. As art became a part of daily life, art infusion becomes a powerful tool for designing, advertising, and packaging activities.

Some experimental studies have been carried out by various researchers on the art infusion effect. According to research conducted by Lee et al. (2015), the use of art in hedonic products positively affects attitudes. They also found that consumers' responses to the use of art in products differ according to product-advertising congruity and advertising-personal image congruity. Similarly, Hagtvedt and Patrick (2008b) demonstrated that the presence of art in product design affects brand image perception and brand extensibility. Moreover, in this case, Naletelich and Paswan (2018) found that using different art types (abstract vs. realistic) in the product design differentiates consumer responses. Mumcu and Kimzan (2015) also demonstrated that the products' visual aesthetic value reduces consumers' price sensitivity by enhancing their perceived prestige and uniqueness.

Furthermore, the art infusion effect develops the luxury perception of the product. In this issue, Hagtvedt and Patrick (2008a) stated that the art infusion in the product is a way of associating the art element with luxury. Logkizidou et al. (2019), benefiting from Hagvedt and Partick's (2008a) research on the art infusion effect, found that the museological product displays create an art infusion effect. Then, they demonstrated that products displayed with art infusion are perceived as more luxurious and purchasable. Baumgarth and Wieker (2020) also confirmed the effects of art infusion using urban art elements on luxury perception and product evaluation.

Although the use of art elements in product design has been primarily seen in luxury products, today, art elements are used in many product types, from sneakers to chocolate packages. Various brands try to make a difference by cooperating with some 
painters and artists to use visual art in their products. For example, a non-luxury sports shoe brand has included some images of Van Gogh's paintings in their products (Van Gogh Museum, 2018). On the other hand, art professionals or amateurs criticize such products, especially on social media. Those criticisms' focus is on marketing commodifies art (Prisant, 2020; Valentish, 2018).

To sum up, it is thought that investigating the art infusion effect on consumer evaluation from various aspects will help to enrich the limited literature and provide a sophisticated understanding for practitioners. However, there is a lack of research that comparatively examines the effects of visual art infusion on quality perception, luxury perception, and product evaluation in different product types. It is expected that this study will contribute to filling this gap by determining the effects of non-luxury products with visual art on consumer evaluations. Accordingly, this study is designed to answer the following research questions:

RQ1: How does the use of visual art in product design (art infusion) affect consumer perceptions and evaluations?

RQ2: How does the effect of art infusion on consumer evaluations differ across the product types?

Depending on these questions, this study aims to determine the effects of using visual art in designing non-luxury products on consumers' luxury perceptions, quality perceptions, and evaluations of the products. The study differs from previous studies in two important ways. First, this study comparatively reveals the effects of art infusion on consumer evaluations according to different product types (convenience vs. shopping). Second, it evaluates these effects by controlling the effects of the consumer aesthetic centrality.

\section{CONCEPTUAL FRAMEWORK AND HYPOTHESES DEVELOPMENT}

The studies related to hypotheses development are discussed in the following headings.

\section{The Use of Visual Art in Product Design}

Homburg et al. (2015) define product design as "the set of constitutive elements of a product that consumers perceive and organize as a multidimensional construct comprising three dimensions of aesthetics, functionality, and symbolism." They state that these constitutive elements can be both visual and non-visual. Moreover, design and aesthetics are naturally linked, as a product's design encompasses the product's aesthetic aspects (Veryzer, 1995). Beautifully designed products have significant 
effects in creating initial impressions and gaining market recognition (Belk, 1988; Bloch et al., 2003). Also, Hoegg et al. (2010) showed that aesthetic design affects consumer's evaluation. Visual aesthetics have a symbolic function that affects how a product is understood and evaluated (Bloch et al., 2003). Therefore, the use of art as a visual element in product design likely to affect consumer reactions.

Schnurr et al. (2017) examined the effect of products' visual appeal on attraction and quality perceptions of conventional and non-conventional products. They concluded that visual appeal positively affects attractiveness and quality perceptions only for non-conventional products. Another critical study examining the use of visual art in product design belongs to Hagtvedt and Patrick (2008a). This article analyzed the relationships among the use of visual art, luxury perception, and product evaluation. Three different sub-studies were conducted within their study, where the boxes containing cutlery, bath cloths, and soap dishes were selected as the product categories. In the first two sub-studies, the change in consumers' perception toward products with visual art and without visual art was examined. In the third sub-study, the perceptions of three products (one with visual art, one without visual art, and one with visual art that evokes negative sentiments) were examined. In all three sub-studies, it was concluded that using visual art positively affects consumer perceptions. Another study that deals with packaging design's aesthetic aspect revealed that attractive designs could bring success among solid brands with high reputations and high prices (Reimann et al., 2010).

\section{Luxury Perception}

Wiedmann et al. (2007) state that the term "luxury" is widely used in daily life, but this term may have different meanings. Because luxury is a relative concept based on people's subjective assessment, and perceptions of people shape it (De Barnier et al., 2012). Possible differences in consumers' perception of luxury also make it difficult to conceptually separate luxury and non-luxury products (Vigneron \& Johnson, 2004). A non-luxury product can be considered a luxury by its consumers, depending on its various attributes (Aliyev et al., 2018). Moreover, Kapferer (2014) drew attention to the relationship between luxury and art. Thus, visual art in product design can be considered one of these attributes that influence luxury perceptions.

Hagtvedt and Patrick (2008b) found that the use of visual art on products enhanced luxury perceptions. Chailan (2018) emphasized that art elements are an instrument for creating value and uniqueness for luxury brands. Lee et al. (2015) also investigated the effect of using visual art on luxury branded products (luxury bags). In that study, it was found that the use of visual art has a positive effect on the conspicuous value, perceived unique value, perceived quality value, and perceived hedonic value, but does not affect 
the extended-self dimension. This study also stated that these effects' size increases if the price of a product with visual art is $25 \%$ or $50 \%$ higher. Huettl and Gierl (2012) examined the relationship between the use of art on hedonic and utilitarian products in terms of price and luxury perception; and found that the use of art only positively affects the luxury perception of hedonic products. Researchers also found that the use of art causes the product perceived as expensive if the price is not mentioned. Kim et al. (2012) found that the use of art elements affects luxury perception and brand image. They also found that luxury perception created by using an art element positively affects product evaluation, and product evaluation positively affects purchase intention. Peluso et al. (2017) found that art infusion increases the luxury perception of the advertised product. They also found that consumers' desire to signal status and desire for distinction moderates their relationship between art infusion and willingness to buy. In another study, Baumgarth and Wieker (2020) found that urban art elements in product design affect luxury perception. Based on these findings, the following hypothesis is proposed:

H1a: The use of visual art in product design affects luxury perception.

\section{Perceived Quality}

Zeithaml (1988) defines perceived quality as consumers' evaluations and judgments about a product's excellence or superiority. Perceived quality is different from objective quality (Zeithaml, 1988). Consumers' quality assessment of a product or a brand is influenced by factors such as price, product characteristics, packaging, brand-manufacturer, advertising activities, word-of-mouth communication, and past purchasing experiences (Jacoby et al., 1971). Ghaani Farashahi et al. (2018) emphasized that the product's appearance also affects consumers' quality perception.

The relationship between product design and perceived quality is emphasized in various studies in the literature. Rigaux-Bricmont (1982) showed that brand packaging affects consumer's quality perception. Hassenzahl (2001) demonstrated that the product's hedonic quality affects the consumer's subjective assessment of its attractiveness. Creusen and Schoormans (2005) showed in a qualitative study that the effect of shape, color, and size of products varies from person to person and affects consumer preferences. Chitturi et al. (2019) found that the product's color and shape affect quality perception and purchasing preference. Based on these findings, the following hypothesis is proposed:

H1b: The use of visual art in product design affects perceived quality. 


\section{Product Evaluation}

Product evaluation can be accepted as an attitude because it is a matter of thought rather than behavior. Fishbein and Ajzen's (1975) theory mentions that the consumers' evaluations based on descriptive, inferential, and informational signs affect attitudes (Zhang, 1996).

Product evaluation is widely studied in the literature because it affects concepts like product preference (MacInnis \& de Mello, 2005) and a product's acceptance or rejection (Hulland, 1999). In some studies, product evaluation is also used instead of concepts such as product preference and purchase intention (Quester et al., 2000). Additionally, since the evaluation of a product or a brand affects the evaluation of a new product or brand that will be launched in the future, product evaluations have become a much more critical subject (Klein \& Dawar, 2004).

In the literature, product evaluation is associated with innovation. Schoormans and Robben (1997) found that new packaging affects product evaluation. Mukherjee and Hoyer (2001) revealed that product innovations affect product evaluation (positively for low complexity products and negatively for high complexity products).

On the other hand, DeBono and Snyder (1989) found that the use of visual art (art infusion) affects product evaluation, willingness to pay more, and purchase intention. Hoegg et al. (2010) showed that aesthetic design affects consumers' evaluation of product functionality. Estes et al. (2018) carried out research examining how the use of visual art in ads affects product value in terms of product evaluation and willingness to buy. They found that art infusion has a mediating role in these relationships, especially for utilitarian products. In another study, Baumgarth and Wieker (2020) revealed that the product's designs with street art and graffiti elements are evaluated more positively than the non-art version of the product. Based on these findings, the following hypothesis is proposed:

H1c: The use of visual art in product design affects product evaluation.

\section{Product Type}

The moderating effect of product type on consumer evaluations is one of the issues elaborated in the literature with different variables (e.g., Filieri et al., 2019; Pan \& Zhang, 2011; Sharma, 2011; Talukdar \& Yu, 2020)

Although the studies on the moderator role of the product type in terms of product design and consumer responses are relatively limited, there are various studies in the literature in this context. Luchs and Kumar (2017) evaluated the moderator role of product type on the effect of product features and aesthetic design on consumer evaluations and the likelihood to purchase. They found that the product type, divided 
into two groups based on hedonic and utilitarian qualities, has a moderator role in these relationships. Amatulli et al. (2017) demonstrated the moderator role of product type in the effect of luxury elements in product and communication on consumer evaluations. They classified products as status-signaling and non-status-signaling and found that the product type had a moderated effect on related relationships. Ghoshal et al. (2012) examined the effect of the packaging appearance on consumers' attitudes towards the product. By classifying the products as hedonic and utilitarian, they found that the type of product had a moderated effect in the related effects. In particular, they demonstrated that aesthetically appealing packaging positively affects product attitudes and valuations for hedonic products. In addition to these studies, Naletelich and Paswan (2018) found that the use of different art forms (a genre of art-realist, abstract, no arts) differentiated the effects on purchase intention of non-luxury products (e.g., sunglasses).

Based on these findings, the present study evaluates that product type moderates the relationships in $\mathrm{H} 1 \mathrm{a}, \mathrm{H} 1 \mathrm{~b}$, and $\mathrm{H} 1 \mathrm{c}$ and propose the following hypotheses:

H2a: Product type moderates the effect of using visual art in product design on perceived quality.

H2b: Product type moderates the effect of using visual art in product design on luxury perception.

H2c: Product type moderates the effect of using visual art in product design on product evaluation.

\section{Consumer Aesthetics Centrality}

The aesthetic value of products has been studied in different areas in marketing literature. Vilches-Montero et al. (2018) defined aesthetic products as products with visuals that evoke positive emotions. They mention that five senses could perceive differences in the design of these products. The product's aesthetic perception and appearance are associated with both luxury and art products in the literature. Eventually, a product's aesthetic perception and appearance are considered significant factors combining luxury and art (Lagier \& Godey, 2007). Horn and Salvendy (2009) pointed out the relationship between the emotional effect created by aesthetics and consumer's creativity. They also emphasize that creativity can be an essential tool in today's economy based on value creation (Horn \& Salvendy, 2006).

Aesthetics is another concept related to visual arts. For this respect, consumer aesthetic centrality can be seen as a significant issue in art infusion within the scope of marketing. Bloch et al. (2003) defined aesthetics centrality as the level of importance given by consumers to a product's aesthetic appearance when determining their 
relationship with the product. Townsend and Sood (2012) found out consumers who give importance to design express themselves this way.

Brunel and Kumar (2007) found a relationship between the seven dimensions of the product's aesthetic perception (simplicity/complexity, harmony, balance, unity, dynamics, timeliness/fashion, and novelty) and the five dimensions of the product personality (sincerity, excitement, competence, sophistication, ruggedness). Another study found that the consumers' aesthetic response changed according to the degree of innovation and complexity of the product (Seifert \& Chattaraman, 2017). Toufani et al. (2017) also found that aesthetic perception indirectly affects three perceived value dimensions (social, functional, emotional).

Based on the above findings, the present study evaluates that the consumer aesthetic centrality affects the perceived quality, luxury perception, and product evaluation. Therefore, consumer aesthetic centrality is defined in this study's design as a covariate. Accordingly, the relationships in $\mathrm{H} 1 \mathrm{a}, \mathrm{H} 1 \mathrm{~b}, \mathrm{H} 1 \mathrm{c}, \mathrm{H} 2 \mathrm{a}, \mathrm{H} 2 \mathrm{~b}$, and $\mathrm{H} 2 \mathrm{c}$ are considered by controlling this covariate's effects. Consequently, the following hypotheses are proposed:

H3a: Consumer aesthetic centrality affects perceived quality.

H3b: Consumer aesthetic centrality affects luxury perception.

H3c: Consumer aesthetic centrality affects product evaluation.

Figure 1 shows the research model based on the present study's hypotheses.

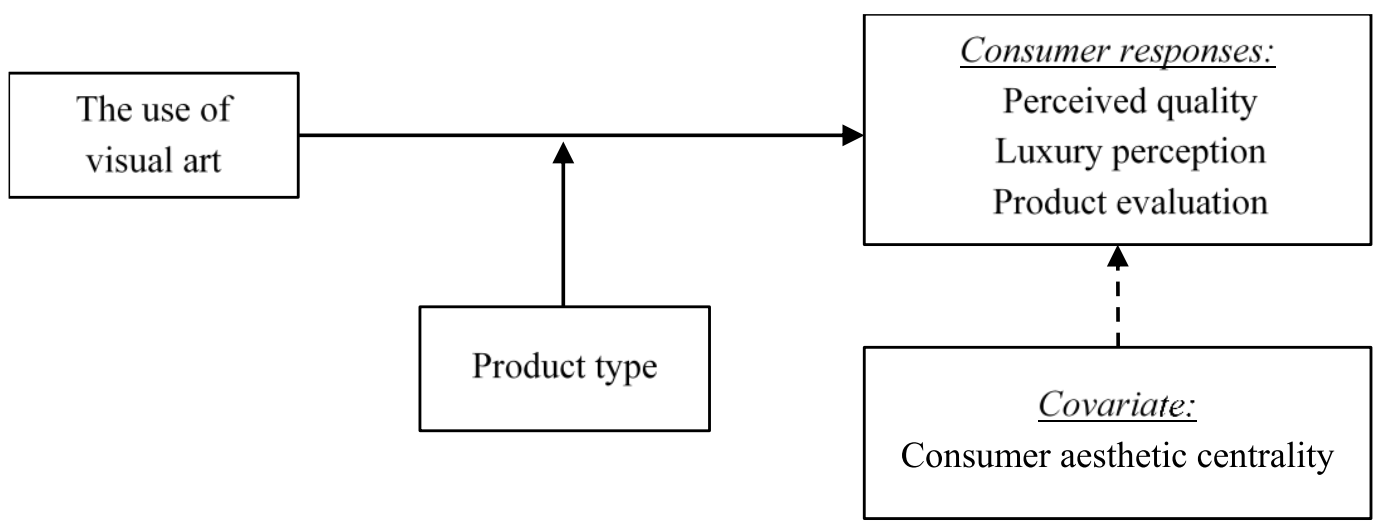

Figure 1 Research Model 


\section{METHODOLOGY}

\section{Experimental Design}

The experimental design was conducted to test the hypotheses (Malhotra, 2010). Experimental groups were formed by conducting $2 \times 2$ between-subjects design (the use of visual art in the product design: no visual art vs. visual art $\mathrm{x}$ product type: convenience product vs. shopping product). The use of visual art in product design was determined as an independent variable, whereas perceived quality, luxury perception, and product evaluation were determined as dependent variables. Product type was also determined as a moderator variable. The differences in the consumers' aesthetic centrality have a probability of differentiating other variables' effects on the dependent variables. In order to control these differences, the consumer aesthetic centrality variable was included as a covariate in the scope of this study.

\section{Measurement}

The scale for perceived quality was adapted from Sweeney and Soutar (2001). The scale for luxury perception was adapted from Vigneron and Johnson (2004). The scale for product evaluation was adapted from Mukherjee and Hoyer (2001) and Peracchio and Tybout (1996). The scale for consumer aesthetic centrality was adapted from Bloch et al. (2003). All scales were measured using 5-point scales ranging from 1 (strongly disagree) to 5 (strongly agree).

The visual art image used in the product design in the experimental treatment was selected based on a pre-test with 80 participants. In this context, by examining and researching open sources on the web, ten well-known visual art pieces were determined. The pre-data collection process was carried out in the classroom environment. These ten images on a single page were presented to the respondents, and respondents were asked to indicate whether they know the image before or not and whether they like the image or not. As a result, a detail from Michelangelo's Creation of Adam fresco, the option with the highest level of recognition and appreciation in the pre-test, was chosen as the experimental image.

On the other hand, in line with the study's aim, the product type is handled to include non-luxury products. In this context, the product type consists of two separate groups: convenience vs. shopping. The reason for this is to determine the effects of using visual arts in two types of products that cannot usually be considered luxurious and to understand how consumers' perception of art infusion differs according to the type of product. Consequently, a single thermos mug was selected for the convenience product, and a laptop was selected for the shopping product. The reason for choosing 
these two products is based on the assumption that young consumers are already using them.

\section{Participants and Data Collection Process}

The research population consisted of young consumers. The reason for this is the assumption that university students have higher levels of awareness about the arts. Vanhaverbeke (1992) pointed out that university students whose cultural knowledge level is above average are a valuable market segment for research.

In the present study, the participants were determined based on the convenience sampling method. Accordingly, the data were collected from 400 university students via a face-to-face survey method. The participants were assigned to each experimental group in equal numbers (100 university students in each group).

The participants responded to the questionnaire of the experimental group that they were assigned. In the questionnaires, a product image was given with an information text. Then, the participants were asked to respond to the questions by considering this product information. Four different questionnaires were used for each experimental group. In the questionnaires, product images and product information texts were manipulated based on the experimental group, but other parts, including questions and items, were kept the same. Table 1 shows the product images and information texts used for different experimental groups. 
Table 1 Product Images and Information Texts Used in the Measurement Process

\begin{tabular}{|c|c|c|}
\hline $\begin{array}{c}\text { Experimental } \\
\text { group }\end{array}$ & Product image & Information text \\
\hline A & & $\begin{array}{l}\text { The single thermos cup you see in the picture is metallic } \\
\text { gray, made of stainless steel. It maintains the temperature } \\
\text { of hot drinks for } 12 \text { hours and cold drinks for } 24 \text { hours. Its } \\
\text { capacity is } 500 \mathrm{ml} \text {. A drinking edge for easy drinking } \\
\text { surrounds it, it has an amount mark, and it is ergonomic. } \\
\text { Thermos is made of lightweight material to carry } \\
\text { comfortably everywhere. It has a cover that provides full } \\
\text { protection. }\end{array}$ \\
\hline B & & $\begin{array}{l}\text { The single thermos cup you see in the picture is metallic } \\
\text { gray, designed using a detailed image from the famous } \\
\text { Italian painter of Renaissance, Michelangelo's Creation of } \\
\text { Adam painting. It maintains the temperature of hot drinks } \\
\text { for } 12 \text { hours and cold drinks for } 24 \text { hours. Its capacity is } \\
500 \mathrm{ml} \text {. A drinking edge for easy drinking surrounds it, it } \\
\text { has an amount mark, and it is ergonomic. Thermos is made } \\
\text { of lightweight material to carry comfortably everywhere. } \\
\text { It has a cover that provides full protection. }\end{array}$ \\
\hline $\mathrm{C}$ & & $\begin{array}{l}\text { The notebook you see in the picture is gray. The computer } \\
\text { has an i7 Intel Core processor, } 4 \mathrm{~GB} \text { of memory, and } 1 \mathrm{~TB} \\
\text { hard drive capacity. It has a } 13.3 \text {-inch thin frame display, } \\
\text { weighs } 1.37 \mathrm{~kg} \text {, and has } 8 \text { hours battery life after charging. }\end{array}$ \\
\hline D & & $\begin{array}{l}\text { The notebook you see in the picture is gray, designed } \\
\text { using a detailed image from the famous Italian painter of } \\
\text { Renaissance, Michelangelo's Creation of Adam painting. } \\
\text { The computer has an i7 Intel Core processor, } 4 \mathrm{~GB} \text { of } \\
\text { memory, and } 1 \mathrm{~TB} \text { hard drive capacity. It has a } 13.3 \text {-inch } \\
\text { thin frame display, weighs } 1.37 \mathrm{~kg} \text {, and has } 8 \text { hours of } \\
\text { battery life after charging. }\end{array}$ \\
\hline
\end{tabular}




\section{FINDINGS}

Exploratory factor analysis (EFA) was used to evaluate the research scales' validity and determine the appropriate factor structures for subsequent analyzes. Principal component analysis and the Varimax rotation method were applied. The items that have factor-loadings of .60 and above were included in the factor structures (Hair et al., 2010). Table 2 shows the factor structures, total variance explained, and Cronbach's alpha values calculated to determine each scale's reliability. Based on the EFA results, it was concluded that the measurement structures of the variables in this study had high explanation rates, and these structures were consistent with the literature. Besides, the reliabilities of all the scales were above the acceptable level (Malhotra, 2010).

Table 2 EFA Results

\begin{tabular}{|c|c|c|c|c|}
\hline Variable & Items & $\lambda$ & TVE & $\alpha$ \\
\hline \multirow[t]{4}{*}{ Perceived qualit } & & & $68.76 \%$ & .772 \\
\hline & This product is well made. & .842 & & \\
\hline & This product is expected to have consistent quality. & .827 & & \\
\hline & This product has an acceptable standard of quality. & .818 & & \\
\hline \multicolumn{2}{|c|}{ Luxury perception } & & $68.54 \%$ & .893 \\
\hline Extended self \& & This product is rewarding. & .882 & & \\
\hline \multirow[t]{5}{*}{ hedonic } & This product is exquisite. & .803 & & \\
\hline & This product is glamorous. & .803 & & \\
\hline & This product is successful. & .797 & & \\
\hline & This product is stunning. & .721 & & \\
\hline & This product is leading. & .626 & & \\
\hline \multirow[t]{4}{*}{ Unique } & This product is unique. & .825 & & \\
\hline & This product is handcrafted. & .785 & & \\
\hline & This product is a rare item. & .729 & & \\
\hline & This product is sophisticated. & .605 & & \\
\hline \multirow[t]{3}{*}{ Conspicuous } & This product is for the wealthy. & .825 & & \\
\hline & This product is expected to be extremely expensive. & .796 & & \\
\hline & This product is an elitist item. & .676 & & \\
\hline \multicolumn{2}{|c|}{ Product evaluation } & & $79.69 \%$ & .867 \\
\hline & This product is useful. & .903 & & \\
\hline & This product is good. & .900 & & \\
\hline & This product is preferable. & .875 & & \\
\hline
\end{tabular}


Table 2 EFA Results (continued)

\begin{tabular}{|c|c|c|c|c|}
\hline Variable & Items & $\lambda$ & TVE & $\alpha$ \\
\hline \multicolumn{3}{|c|}{ Aesthetics centrality } & $72.65 \%$ & .874 \\
\hline \multirow[t]{4}{*}{ Acumen } & $\begin{array}{l}\text { I notice things in product designs that other people } \\
\text { tend to overlook. }\end{array}$ & .846 & & \\
\hline & $\begin{array}{l}\text { I understand how a product can best differ from its } \\
\text { competitors with its design. }\end{array}$ & .790 & & \\
\hline & $\begin{array}{l}\text { Being able to see subtle differences in product } \\
\text { designs is a skill that I have developed over time. }\end{array}$ & .718 & & \\
\hline & $\begin{array}{l}\text { I can imagine how a product will fit in with designs } \\
\text { of other things I already own. }\end{array}$ & .708 & & \\
\hline \multirow[t]{3}{*}{ Value } & $\begin{array}{l}\text { I like to look at displays of products that have } \\
\text { superior designs. }\end{array}$ & .846 & & \\
\hline & $\begin{array}{l}\text { Owning products that have superior designs makes } \\
\text { me feel good. }\end{array}$ & .831 & & \\
\hline & A product's design is a source of pleasure for me. & .816 & & \\
\hline \multirow[t]{3}{*}{ Response } & $\begin{array}{l}\text { If a product's design really impresses me, I feel that I } \\
\text { must buy it. }\end{array}$ & .889 & & \\
\hline & I surely want to buy a product that I like its design. & .863 & & \\
\hline & Sometimes a product can only grab me with its looks. & .717 & & \\
\hline \multirow[t]{4}{*}{ Prior knowledge } & & & $73.22 \%$ & .817 \\
\hline & $\begin{array}{l}\text { I think I know more about this product than the } \\
\text { people around me. }\end{array}$ & .914 & & \\
\hline & I have enough knowledge about this product. & .871 & & \\
\hline & $\begin{array}{l}\text { I think I know more about this product than an } \\
\text { expert. }\end{array}$ & .776 & & \\
\hline
\end{tabular}

* Note: $\lambda=$ Item loadings; $T V E=$ Total variance explained; $\alpha=$ Cronbach's alpha

In order to ensure that four different experimental groups were equivalent, the similarity between the groups was examined based on gender, age, and prior knowledge about the product type, separately. The scale for prior knowledge was adapted from Flynn and Goldsmith (1999). In this context, one-way ANOVA was used to evaluate the differences in prior knowledge, whereas chi-square analysis was used to assess the differences in gender and age. As a result, it was concluded that prior knowledge, gender, and age did not differ between the experimental groups [ $F_{\text {prior knowledge }}(3$, $396)=1.338, p=.262 ; \chi_{\text {gender }}^{2}=3.899, p=.273 ; \chi^{2}$ age $\left.=4.031, p=.909\right]$. With this approach, the experimental groups were considered to be similar. 
Multivariate covariance analysis (MANCOVA) was used to evaluate the effects of the use of visual art and product type on perceived quality, luxury perception, and product evaluation, by controlling the effects of consumer aesthetic centrality on dependent variables (Hair et al., 2010). In the two-way MANCOVA analysis, consumer aesthetic centrality was defined as a covariate, and the differentiating effects of this variable on the dependent variables were controlled and adjusted. Firstly, the assumptions of MANCOVA were evaluated. Accordingly, Pearson correlation values were checked, and there was no multicollinearity problem $(|r|<.90)$. As a result of Box's $\mathrm{M}$ test, covariance matrices were homogeneous $(p>.001)$. Studentized residuals were normally distributed, as assessed by Shapiro-Wilk's test $(p>.05)$.

According to two-way MANCOVA analysis, the effects of the independent variables (the use of visual art and product type), the interactions (the use of visual art $\mathrm{x}$ product type), and the covariate (aesthetic centrality) on the dependent variables (perceived quality, luxury perception, product evaluation) were assessed. Table 3 shows the analysis results. Besides, it also shows the $\mathrm{F}$ values and significance levels calculated using the univariate two-way ANCOVA analysis separately for evaluating the effects of the independent variables on each of the dependent variables.

Table 3 MANCOVA Results

\begin{tabular}{|c|c|c|c|c|c|}
\hline \multirow[b]{2}{*}{ Effects } & \multicolumn{2}{|c|}{$\underline{\text { Multivariate tests }}$} & \multicolumn{3}{|c|}{ Tests of between-subjects effects } \\
\hline & Wilks' $\Lambda$ & $F(3,393)$ & $\begin{array}{c}\text { Perceived } \\
\text { quality } \\
F_{1}(1,395) \\
\end{array}$ & $\begin{array}{c}\text { Luxury } \\
\text { perception } \\
F_{2}(1,395) \\
\end{array}$ & $\begin{array}{c}\text { Product } \\
\text { evaluation } \\
F_{3}(1,395) \\
\end{array}$ \\
\hline \multicolumn{6}{|l|}{ Main effects } \\
\hline The use of visual art (A) & .933 & $9.474^{*}$ & .112 & $13.891 *$ & 1.775 \\
\hline Product type (B) & .806 & $31.475^{*}$ & $48.675^{*}$ & $16.501 *$ & $4.440 * * *$ \\
\hline \multicolumn{6}{|l|}{ Covariate } \\
\hline Aesthetic centrality & .828 & $27.241 *$ & $22.017 *$ & $66.219 *$ & $58.199 *$ \\
\hline \multicolumn{6}{|l|}{ Interaction effects } \\
\hline $\mathrm{A} \times \mathrm{B}$ & .972 & $3.743 * *$ & .505 & .122 & $8.478 * *$ \\
\hline
\end{tabular}

As a result of the two-way MANCOVA analysis, the effect of aesthetic centrality on the combination of dependent variables was found to be statistically significant

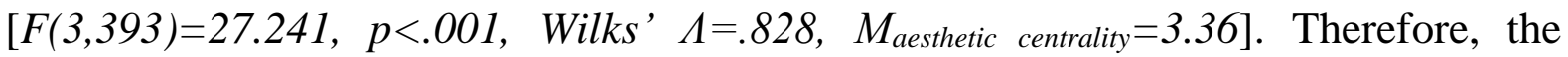
adjusted means were calculated by controlling this effect, and other effects were evaluated based on these adjusted means. Accordingly, the main effects of the use of visual art variable $[\mathrm{F}(3,393)=9.474, p<.001$, Wilks' $\Lambda=.933]$ and product type variable 
$[F(3,393)=31.475, p<.001$, Wilks' $\Lambda=.806]$, and the interaction effect between them $\left[F(3,393)=3.743, p<.01\right.$ Wilks' $\left.^{\prime} \Lambda=.972\right]$ on the combination of dependent variables are statistically significant.

As a result of the univariate two-way ANCOVA analysis, it was also found that the effects of aesthetic centrality as a covariate on perceived quality, luxury perception, and product evaluation are statistically significant $\left[F_{1}(1,395)=22.017, p<.001\right.$; $\left.F_{2}(1,395)=66.219, p<.001 ; F_{3}(1.395)=58.199, p<.001\right]$. Therefore, while controlling for aesthetic centrality, the adjusted means for luxury perception is significantly different between different groups of the use of visual art variable $\left[F_{2}(1,395)=13.891\right.$, $p<.001]$, but there is no significant difference in the adjusted means for other dependent variables $\left[F_{1}(1,395)=.112, p>.05 ; F_{3}(1,395)=1.775, p>.05\right]$. On the other hand, there are statistically significant differences in the adjusted means for perceived quality, luxury perception, and product evaluation between different groups of product type $\left[F_{1}(1,395)=48.675, p<.001 ; F_{2}(1,395)=16.501, p<.001 ; F_{3}(1,395)=4.440, p<.05\right]$. Moreover, the interaction between the use of visual art and product type is statistically significant on product evaluation $\left[F_{3}(1,395)=8.478, p<.01\right]$, but there are no significant differences in the adjusted means for perceived quality and luxury perception $\left[F_{1}(1,395)=.505, p>.05 ; F_{2}(1,395)=.122, p>.05\right]$.

Depending on the analyses utilized, the status of the study's hypotheses $(p<.05)$ is summarized in table 4.

Table 4 Summary of Hypotheses

\section{Hypotheses}

Supported

1a The use of visual art in product design affects luxury perception. or not

$1 \mathrm{~b}$ The use of visual art in product design affects perceived quality.

Yes

1c The use of visual art in product design affects product evaluation.

No

2a Product type moderates the effect of using visual art in product design

No on perceived quality.

2b Product type moderates the effect of using visual art in product design No on luxury perception.

2c Product type moderates the effect of using visual art in product design Yes on product evaluation.

3a Consumer aesthetic centrality affects perceived quality.

Yes

$3 \mathrm{~b}$ Consumer aesthetic centrality affects luxury perception.

Yes

3c Consumer aesthetic centrality affects product evaluation.

Yes 


\section{Main effects}

In terms of simple main effects, according to the adjusted means for luxury perception, the products with visual art $\left(M_{1}=2.95\right)$ have a higher value than the products without visual art $\left(M_{2}=2.69\right)$ (see Figure 2).

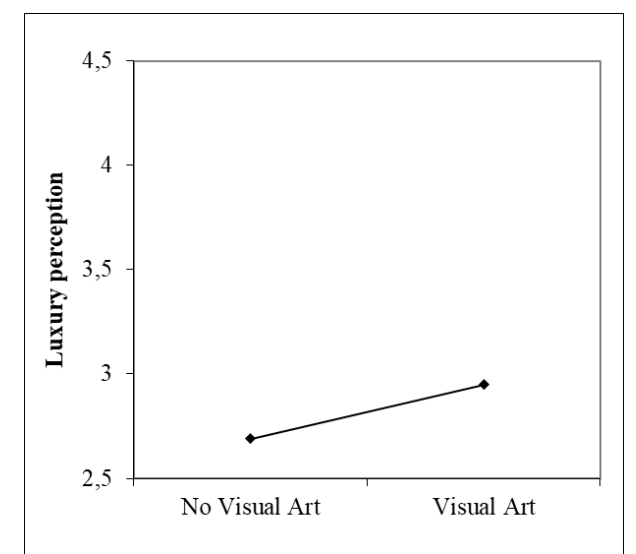

Figure 2 Change of Luxury Perception According to the Use of Visual Art

Moreover, according to the adjusted means for luxury perception, it is seen that the convenience product $\left(M_{3}=2.68\right)$ has a lower value than the shopping product $\left(M_{4}=2.96\right)$. In contrast, it is seen that the convenience product $\left(M_{5}=4.11\right)$ has a higher value than the shopping product $\left(M_{6}=3.62\right)$ according to the adjusted means for perceived quality. On the other hand, according to the adjusted means for product evaluation, the convenience product $\left(M_{7}=3.66\right)$ has a higher value than the shopping product $\left(M_{8}=3.50\right)$ (see Figure 3).
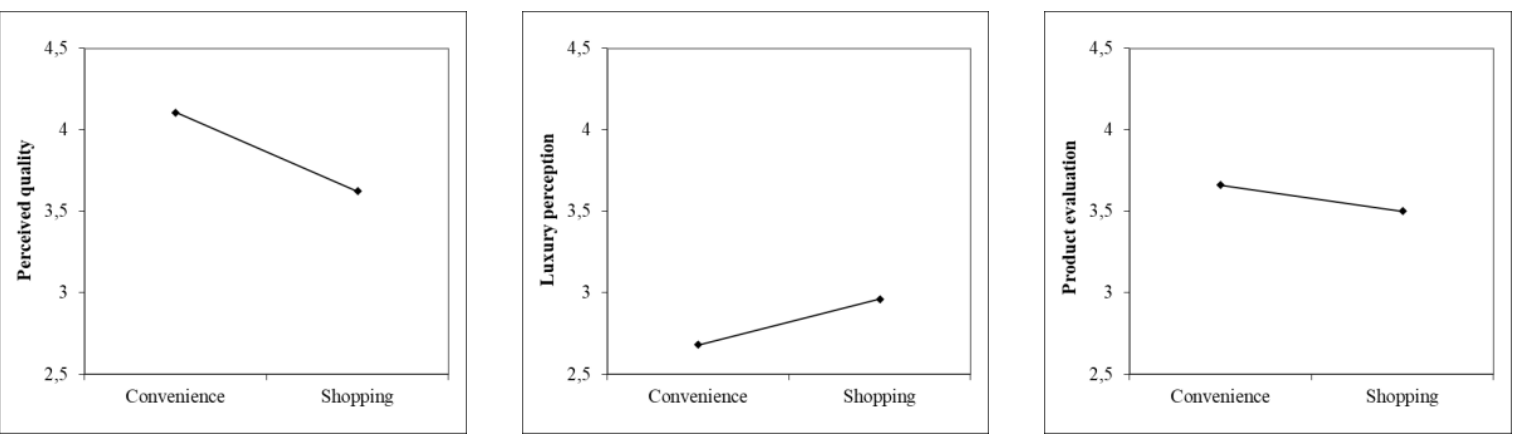

Figure 3 Changes of Perceived Quality, Luxury Perception, and Product Evaluation According to Product Type 


\section{Interaction effects}

According to the interaction effect between the use of visual art and product type, there are no significant differences in the groups according to the adjusted means for perceived quality and luxury perception ( $\mathrm{p}>.05$ ). On the other hand, there is a significant difference in interaction effects on product evaluation $(\mathrm{p}<.000)$ (see Figure 4$)$.

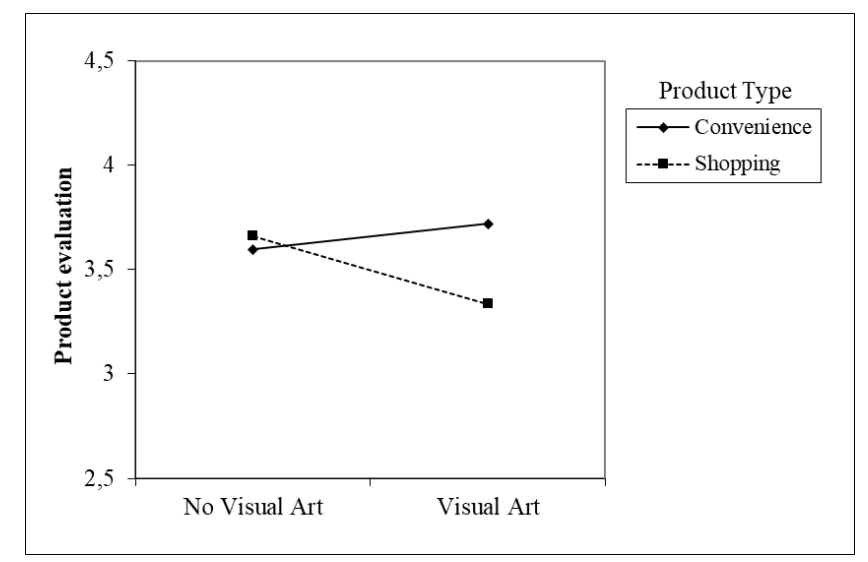

Figure 4 Change of Product Evaluation According to the Interaction between the Use of Visual Art and Product Type

According to the adjusted means for the product evaluation, it is seen that the convenience product without visual art $\left(M_{9}=3.60\right)$ and the shopping product without visual art $\left(M_{10}=3.66\right)$ have almost similar value, whereas the convenience product with visual art $\left(M_{11}=3.72\right)$ has a higher value than the shopping product with visual art $\left(M_{12}=3.34\right)$. Moreover, according to the adjusted means for the product evaluation, the shopping product without visual art has a higher value than the shopping product with visual art $\left(M_{10}-M_{12}=.32\right)$, while the convenience product with visual art has a higher

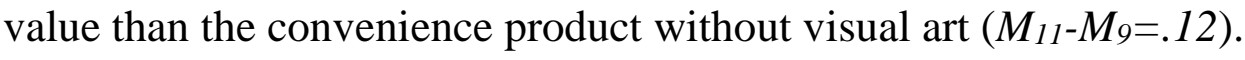

\section{CONCLUSION}

The present study examines the effects of using visual art in the product design on perceived quality, luxury perception, and product evaluation. As a result, it is found that the use of visual art in product design and the product type, both separately and together, have effects on perceived quality, luxury perception, and product evaluation.

\section{Visual Art and Consumer Responses}

Art infusion effect on consumer responses is an outstanding topic but scarcely discussed in the literature. Perception and product evaluation (Hagtvedt \& Patrick, 2008a), brand image and expansion (Hagtvedt \& Patrick, 2008b), attitudes (Lee et al., 2015), consumer responses (Naletelich \& Paswan, 2018) are among the variables 
studied within the scope of this phenomenon. On the other hand, Kapferer (2014) emphasized the relationship between art and luxury. Luxury perception in terms of art infusion is also one of the prominent research areas. Studies in the literature show that artistic elements affect luxury perception (Baumgarth \& Wieker, 2020; Hagvedt \& Partick, 2008a, Huettl \& Gierl, 2012; Kim et al., 2012; Logkizidou et al., 2019; Peluso et al., 2017). In line with these studies, the present study was evaluated whether the use of visual art in product design affects consumer reactions in terms of quality perception, luxury perception, and product evaluation. Accordingly, this study demonstrated that the use of visual art in product design has a significant effect on luxury perception but does not significantly affect the perceived quality and product evaluation. As a result, the use of visual art in product design increases the luxury perception.

\section{The Moderating Role of Product Type}

The use of visual art in product design started in luxury products, but currently, the art infusion phenomenon has started to be seen in many product types. Based on this, the present study is focused on the moderating role of product type (convenience vs. shopping).

Before evaluating the product type's moderating role, the product type's direct effects on consumer responses were examined. As a result, the present study demonstrated that the product type affects luxury perception, quality perception, and product evaluation. Accordingly, luxury perception is higher for shopping products than convenience products. Moreover, perceived quality and product evaluation are higher for convenience products than shopping products.

Next, the moderating role of product type on visual art effects on consumer responses was examined. As a result, this study reveals that product evaluation's interaction effect was significant, but not on perceptions of luxury and quality perceptions. According to this, when visual art is used in product design, consumers evaluate convenience products more positively than shopping products. On the contrary, when visual art is not used in product design, consumers have a higher positive evaluation of shopping products than convenience products. As a result, visual art increases positive product evaluations for convenience products but decreases it for shopping products. Thus, product type has a moderating role on the effects of using visual art on product evaluation.

As a result of all the study findings, it is concluded that art infusion in the ordinary and non-luxury products, which do not contain technical details and where consumers make rapid evaluations for purchasing, increases the consumers' positive evaluations of these products. However, these effects are reversed in more qualified product groups. Additionally, the use of visual art and the product type affect luxury perception 
separately. Specifically, visual art in the design of non-luxury products improves these products' luxury perception. This situation can be interpreted as visual art offers an effective design alternative in making more simple products attractive to the consumer. On the other hand, in products with technical details, consumers need a more rational decision-making process, and visuality stays in the background.

This study differs from previous studies in the literature (e.g., Hagtvedt \& Patrick, 2008a; Hagtvedt \& Patrick, 2008b; Lee et al., 2015) with examining the effects of art infusion according to product types (convenience vs. shopping) separately. In this context, product type has a moderating role in the effects of visual art in product design on consumer evaluation. In particular, it is thought that determining the positive effects of art infusion in product design on consumer evaluations and defining their comparative states will significantly contribute to the literature.

This study also examines the effects of aesthetic centrality on consumer perceptions and evaluations by controlling the effects of the consumer aesthetic centrality. In this respect, the study offers original contributions to the literature. On the other hand, visual art may be a valuable tool to enhance consumer's product evaluations in purchasing simple products for practitioners. As products' visual aesthetic value reduces consumers' price sensitivity by enhancing perceived prestige and uniqueness (Mumcu \& Kimzan, 2015), this approach can also be seen as a means of offering premium prices for companies.

\section{Limitations and Suggestions for Further Research}

In this study, only one product has represented each product group, and only one specific art image has been used. Additionally, the study's participants consist of only young consumers. Besides, this study has a quasi-experimental design. It is suggested that the findings of the study should be evaluated within these limitations. For future studies, it is recommended that this study's method and approach should be improved to eliminate these limitations.

On the other hand, the differentiation according to the product type and results concerning technical details brought the idea that the study findings may differ according to consumer characteristics. In this respect, reinvestigating this study's design and different consumer thinking styles may reveal essential findings. Besides, based on the finding that the art element strengthens the luxury perception in non-luxury products, it is suggested that the study's approach is handled together with consumer's luxury consumption motifs. 


\section{REFERENCES}

Aliyev, F., Ürkmez, T., \& Wagner, R. (2018). Luxury brands do not glitter equally for everyone. Journal of Brand Management, 25(4), 337-350.

https://doi.org/10.1057/s41262-017-0085-x

Amatulli, C., De Angelis, M., Costabile, M., \& Guido, G. (2017). Sustainable Luxury Brands. Palgrave Macmillan UK. https://doi.org/10.1057/978-1-137-60159-9

Baumgarth, C., \& Wieker, J. B. (2020). From the classical art to the urban art infusion effect: The effect of street art and graffiti on the consumer evaluation of products. Creativity and Innovation Management, 1-12.

https://doi.org/10.1111/caim.12362

Belk, R. W. (1988). Possessions and the extended self. Journal of Consumer Research, 15(2), 139-168. https://doi.org/10.1086/209154

Bloch, P. H. (1995). Seeking the ideal form: Product design and consumer response. Journal of Marketing, 59(3), 16-29. https://doi.org/10.1177/002224299505900302

Bloch, P. H., Brunel, F. F., \& Arnold, T. J. (2003). Individual differences in the centrality of visual product aesthetics: Concept and measurement. Journal of Consumer Research, 29(4), 551-565. https://doi.org/10.1086/346250

Brunel, F. F., \& Kumar, R. (2007). Design and the big five: Linking visual product aesthetics to product personality. In G. Fitzsimons \& V. Morwitz (Eds.), NA Advances in Consumer Research Volume 34 (pp. 238-239). Association for Consumer Research.

Chailan, C. (2018). Art as a means to recreate luxury brands' rarity and value. Journal of Business Research, 85, 414-423. https://doi.org/10.1016/j.jbusres.2017.10.019

Chitturi, R., Londono, J. C., \& Amezquita, C. A. (2019). The influence of color and shape of package design on consumer preference: The case of orange juice. International Journal of Innovation and Economic Development, 5(2), 42-56. https://doi.org/10.18775/ijied.1849-7551-7020.2015.52.2003

Chitturi, R., Raghunathan, R., \& Mahajan, V. (2008). Delight by design: The role of hedonic versus utilitarian benefits. Journal of Marketing, 72(3), 48-63. https://doi.org/10.1509/jmkg.72.3.48

Creusen, M. E. H., \& Schoormans, J. P. L. (2005). The different roles of product appearance in consumer choice. Journal of Product Innovation Management, 22(1), 63-81. https://doi.org/10.1111/j.0737-6782.2005.00103.x

De Barnier, V., Falcy, S., \& Valette-Florence, P. (2012). Do consumers perceive three levels of luxury? A comparison of accessible, intermediate and inaccessible luxury brands. Journal of Brand Management, 19(7), 623-636. https://doi.org/10.1057/bm.2012.11 
DeBono, K. G., \& Snyder, M. (1989). Understanding consumer decision-making processes: The role of form and function in product evaluation. Journal of Applied Social Psychology, 19(5), 416-424. https://doi.org/10.1111/j.15591816.1989.tb00064.x

Estes, Z., Brotto, L., \& Busacca, B. (2018). The value of art in marketing: An emotion-based model of how artworks in ads improve product evaluations. Journal of Business Research, 85(October 2017), 396-405. https://doi.org/10.1016/j.jbusres.2017.10.017

Filieri, R., Raguseo, E., \& Vitari, C. (2019). What moderates the influence of extremely negative ratings? The role of review and reviewer characteristics. International Journal of Hospitality Management, 77, 333-341. https://doi.org/10.1016/j.ijhm.2018.07.013

Fishbein, M., \& Ajzen, I. (1975). Belief, Attitude, Intention, and Behavior An Introduction to Theory and Research. Addison-Wesley.

Flynn, L. R., \& Goldsmith, R. E. (1999). A short, reliable measure of subjective knowledge. Journal of Business Research, 46(1), 57-66.

https://doi.org/10.1016/S0148-2963(98)00057-5

Ghaani Farashahi, B., Easter, E., \& Annett-Hitchcock, K. (2018). Price and perceived product quality: A comparison of denim jeans in three price categories. Journal of Fashion Marketing and Management: An International Journal, 22(3), 369386. https://doi.org/10.1108/JFMM-10-2017-0104

Ghoshal, T., Boatwright, P., \& Cagan, J. (2012). Do we judge a book by its cover? Unwrapping the role of visually appealing packaging in product evaluation. In $\mathrm{Z}$. Gürhan-Canli, C. Otnes, \& R. (Juliet) Zhu (Eds.), NA - Advances in Consumer Research Volume 40 (pp. 1123-1123). Association for Consumer Research.

Hagtvedt, H., \& Patrick, V. M. (2008a). Art infusion: The influence of visual art on the perception and evaluation of consumer products. Journal of Marketing Research, 45(3), 379-389. https://doi.org/10.1509/jmkr.45.3.379

Hagtvedt, H., \& Patrick, V. M. (2008b). Art and the brand: The role of visual art in enhancing brand extendibility. Journal of Consumer Psychology, 18(3), 212222. https://doi.org/10.1016/j.jcps.2008.04.010

Hair, J. F., Black, W. C., Babin, B. J., \& Anderson, R. E. (2010). Multivariate Data Analysis (7th ed.). Pearson Education.

Hassenzahl, M. (2001). The effect of perceived hedonic quality on product appealingness. International Journal of Human-Computer Interaction, 13(4), 481-499. https://doi.org/10.1207/S15327590IJHC1304_07 
Hoegg, J., Alba, J. W., \& Dahl, D. W. (2010). The good, the bad, and the ugly: Influence of aesthetics on product feature judgments. Journal of Consumer Psychology, 20(4), 419-430. https://doi.org/10.1016/j.jcps.2010.07.002

Homburg, C., Schwemmle, M., \& Kuehnl, C. (2015). New product design: Concept, measurement, and consequences. Journal of Marketing, 79(3), 41-56. https://doi.org/10.1509/jm.14.0199

Horn, D., \& Salvendy, G. (2006). Consumer-based assessment of product creativity: A review and reappraisal. Human Factors and Ergonomics in Manufacturing, 16(2), 155-175. https://doi.org/10.1002/hfm.20047

Horn, D., \& Salvendy, G. (2009). Measuring consumer perception of product creativity: Impact on satisfaction and purchasability. Human Factors and Ergonomics in Manufacturing, 19(3), 223-240.

https://doi.org/10.1002/hfm.20150

Huettl, V., \& Gierl, H. (2012). Visual art in advertising: The effects of utilitarian vs. hedonic product positioning and price information. Marketing Letters, 23(3), 893-904. https://doi.org/10.1007/s11002-012-9196-z

Hulland, J. S. (1999). The effects of country-of-brand and brand name on product evaluation and consideration. Journal of International Consumer Marketing, 11(1), 23-40. https://doi.org/10.1300/J046v11n01_03

Jacoby, J., Olson, J. C., \& Haddock, R. A. (1971). Price, brand name, and product composition characteristics as determinants of perceived quality. Journal of Applied Psychology, 55(6), 570-579. https://doi.org/10.1037/h0032045

Kapferer, J. N. (2014). The artification of luxury: From artisans to artists. Business Horizons, 57(3), 371-380. https://doi.org/10.1016/j.bushor.2013.12.007

Kim, K., Ko, E., \& Lee, Y.-I. (2012). Art infusion in fashion product: The influence of visual art on product evaluation and purchase intention of consumers. Journal of Global Fashion Marketing, 3(4), 180-186.

https://doi.org/10.1080/20932685.2012.10600848

Klein, J., \& Dawar, N. (2004). Corporate social responsibility and consumers' attributions and brand evaluations in a product-harm crisis. International Journal of Research in Marketing, 21(3), 203-217.

https://doi.org/10.1016/j.ijresmar.2003.12.003

Lagier, J., \& Godey, B. (2007). A scale for measuring aesthetic style in the field of luxury and art products. International Journal of Arts Management, 9(2), 39-50. https://www.jstor.org/stable/41064918

Lee, H.-C., Chen, W.-W., \& Wang, C.-W. (2015). The role of visual art in enhancing perceived prestige of luxury brands. Marketing Letters, 26(4), 593-606.

https://doi.org/10.1007/s11002-014-9292-3 
Logkizidou, M., Bottomley, P., Angell, R., \& Evanschitzky, H. (2019). Why museological merchandise displays enhance luxury product evaluations: An extended art infusion effect. Journal of Retailing, 95(1), 67-82.

https://doi.org/10.1016/j.jretai.2018.11.001

Luchs, M. G., \& Kumar, M. (2017). "Yes, but this other one looks better/works better": How do consumers respond to trade-offs between sustainability and other valued attributes? Journal of Business Ethics, 140(3), 567-584.

https://doi.org/10.1007/s10551-015-2695-0

MacInnis, D. J., \& de Mello, G. E. (2005). The concept of hope and its relevance to product evaluation and choice. Journal of Marketing, 69(1), 1-14. https://doi.org/10.1509/jmkg.69.1.1.55513

Malhotra, N. K. (2010). Marketing Research: An Applied Orientation (6th ed.). Pearson Education.

Mukherjee, A., \& Hoyer, W. D. (2001). The effect of novel attributes on product evaluation. Journal of Consumer Research, 28(3), 462-472.

https://doi.org/10.1086/323733

Mumcu, Y., \& Kimzan, H. S. (2015). The effect of visual product aesthetics on consumers' price sensitivity. Procedia Economics and Finance, 26(15), 528-534. https://doi.org/10.1016/S2212-5671(15)00883-7

Naletelich, K., \& Paswan, A. K. (2018). Art infusion in retailing: The effect of art genres. Journal of Business Research, 85, 514-522.

https://doi.org/10.1016/j.jbusres.2017.10.030

Pan, Y., \& Zhang, J. Q. (2011). Born unequal: A study of the helpfulness of usergenerated product reviews. Journal of Retailing, 87(4), 598-612. https://doi.org/10.1016/j.jretai.2011.05.002

Peluso, A. M., Pino, G., Amatulli, C., \& Guido, G. (2017). Luxury advertising and recognizable artworks: New insights on the "art infusion" effect. European Journal of Marketing, 51(11-12), 2192-2206. https://doi.org/10.1108/EJM-092016-0496

Peracchio, L. A., \& Tybout, A. M. (1996). The moderating role of prior knowledge in schema-based product evaluation. Journal of Consumer Research, 23(3), 177192. https://doi.org/10.1086/209476

Prisant, B. (2020). The Commodification Of Contemporary Art? https://www.forbes.com/sites/bardenprisant/2020/03/25/the-commodification-ofcontemporary-art/

Quester, P. G., Karunaratna, A., \& Kee Goh, L. (2000). Self-congruity and product evaluation: a cross-cultural study. Journal of Consumer Marketing, 17(6), 525535. https://doi.org/10.1108/07363760010349939 
Reimann, M., Zaichkowsky, J., Neuhaus, C., Bender, T., \& Weber, B. (2010). Aesthetic package design: A behavioral, neural, and psychological investigation. Journal of Consumer Psychology, 20(4), 431-441. https://doi.org/10.1016/j.jcps.2010.06.009

Rigaux-Bricmont, B. (1982). Influences of brand name and packaging on perceived quality. In A. Mitchell \& A. Abor (Eds.), NA - Advances in Consumer Research Volume 09 (pp. 472-477). Association for Consumer Research.

Schnurr, B., Brunner-Sperdin, A., \& Stokburger-Sauer, N. E. (2017). The effect of context attractiveness on product attractiveness and product quality: The moderating role of product familiarity. Marketing Letters, 28(2), 241-253. https://doi.org/10.1007/s11002-016-9404-3

Schoormans, J. P. L., \& Robben, H. S. J. (1997). The effect of new package design on product attention, categorization and evaluation. Journal of Economic Psychology, 18(2-3), 271-287. https://doi.org/10.1016/S0167-4870(97)00008-1

Seifert, C., \& Chattaraman, V. (2017). Too new or too complex? Why consumers' aesthetic sensitivity matters in apparel design evaluation. Journal of Fashion Marketing and Management: An International Journal, 21(2), 262-276. https://doi.org/10.1108/JFMM-10-2016-0092

Sharma, P. (2011). Demystifying cultural differences in country-of-origin effects: Exploring the moderating roles of product type, consumption context, and involvement. Journal of International Consumer Marketing, 23(5), 344-364. https://doi.org/10.1080/08961530.2011.602952

Sweeney, J. C., \& Soutar, G. N. (2001). Consumer perceived value: The development of a multiple item scale. Journal of Retailing, 77(2), 203-220.

https://doi.org/10.1016/S0022-4359(01)00041-0

Talukdar, N., \& Yu, S. (2020). Do materialists care about sustainable luxury? Marketing Intelligence \& Planning, 38(4), 465-478. https://doi.org/10.1108/MIP-05-2019-0277

Toufani, S., Stanton, J. P., \& Chikweche, T. (2017). The importance of aesthetics on customers' intentions to purchase smartphones. Marketing Intelligence \& Planning, 35(3), 316-338. https://doi.org/10.1108/MIP-12-2015-0230

Townsend, C., \& Sood, S. (2012). Self-affirmation through the choice of highly aesthetic products. Journal of Consumer Research, 39(2), 415-428. https://doi.org/10.1086/663775

Valentish, J. (2018). The commodification of Frida Kahlo: Are we losing the artist under the kitsch? https://www.theguardian.com/artanddesign/2018/dec/29/thecommodification-of-frida-kahlo-are-we-losing-the-artist-under-the-kitsch 
Van Gogh Museum. (2018). Vans collection inspired by Van Gogh.

https://www.vangoghmuseum.nl/en/about/news-and-press/news/vans-collectioninspired-by-van-gogh

Vanhaverbeke, W. (1992). How students evaluate business sponsorship of the arts in flanders. Journal of Cultural Economics, 16(1), 53-66.

https://doi.org/10.1007/BF02275977

Veryzer, J. R. W. (1995). The place of product design and aesthetics in consumer research. In F. R. Kardes \& M. Sujan (Eds.), NA - Advances in Consumer Research Volume 22 (pp. 641-645). Association for Consumer Research.

Vigneron, F., \& Johnson, L. W. (2004). Measuring perceptions of brand luxury. Journal of Brand Management, 11(6), 484-506.

https://doi.org/10.1057/palgrave.bm.2540194

Vilches-Montero, S., Nik Hashim, N. M. H., Pandit, A., \& Bravo-Olavarria, R. (2018). Using the senses to evaluate aesthetic products at the point of sale: The moderating role of consumers' goals. Journal of Retailing and Consumer Services, 40, 82-90. https://doi.org/10.1016/j.jretconser.2017.09.008

Wiedmann, K.-P., Hennigs, N., \& Siebels, A. (2007). Measuring consumers' luxury value perception: A cross-cultural framework. Academy of Marketing Science Review, 11(7), 1-21.

Zeithaml, V. A. (1988). Consumer perceptions of price, quality, and value: A meansend model and synthesis of evidence. Journal of Marketing, 52(3), 2-22. https://doi.org/10.2307/1251446

Zhang, Y. (1996). Chinese consumers' evaluation of foreign products: the influence of culture, product types and product presentation format. European Journal of Marketing, 30(12), 50-68. https://doi.org/10.1108/03090569610153309

Ms. Aylin Ecem Gürşen is a research assistant and Ph.D. candidate at Galatasaray University, Department of Business Administration. Her research focuses on consumer behavior, art marketing, marketing communication, and marketing research.

Dr. Erdem Özkan (Corresponding author) is currently an assistant professor of marketing at Istanbul University School of Business. His research focuses on consumer behavior, marketing research, digital marketing, services marketing, marketing analytics, and advanced research techniques in marketing. He has many publications in international and national journals. 
Dr. Zehra Bozbay is an associate professor of marketing at the Istanbul University School of Business. She received her Ph.D. degree in marketing in 2007 and MS degree in marketing in 2003 from Istanbul University. She has guest lectured several times in undergraduate, graduate and doctorate courses like marketing management, consumer behavior, brand management, research methodology, advanced research techniques, and qualitative research. She has published in many international and national journals and attended many international and national conferences. Her research area of interest covers consumer behavior, brand management, retailing, green marketing, digital marketing, and international marketing. 